\title{
Ontogenetic development of Heterocharax macrolepis Eigenmann (Ostariophysi: Characiformes: Characidae) with comments on the form of the yolk sac in the Heterocharacinae
}

\author{
George M. T. Mattox ${ }^{1}$, Martin Hoffmann² and Peter Hoffmann ${ }^{3}$
}

Fishes in early developmental stages frequently have morphological features that differ from those of adult stages, and many characters found later in ontogeny are not available in initial stages. Hence, morphological descriptions of early stages are useful to provide information for the identification of eggs and larvae, a knowledge still restricted among Neotropical fishes. We studied the development of Heterocharax macrolepis, a heterocharacine whose adult specimens from the aquarium trade were kept and spawned at around $23-24^{\circ} \mathrm{C}$. A developmental series of 51 specimens was preserved, ranging from $3.2 \mathrm{~mm}$ notochord length to $18.6 \mathrm{~mm}$ standard length, covering approximately the first 73 days post-hatching. We described the development of main morphological features emphasizing those useful in the identification of $H$. macrolepis larvae (i.e., appearance of preopercle spine and development of the pseudotympanum). We also compared H. macrolepis with photographs taken of live larval specimens of Gnathocharax steindachneri, recently included in the Heterocharacinae. Both species have a yolk sac with a small rounded projection directed posteroventrally. Although this information is not yet available for all pertinent taxa, the different yolk sac shape in other representatives of the Characiformes may indicate that this peculiar yolk sac represents an additional synapomorphy of the Heterocharacini.

Peixes em estágios iniciais de desenvolvimento frequentemente apresentam características morfológicas distintas dos adultos e muitos caracteres presentes em estágios avançados não são disponíveis em estágios iniciais. Assim, descrições morfológicas dos estágios iniciais de desenvolvimento de peixes são úteis por fornecerem subsídios para a identificação de ovos e larvas, um conhecimento ainda escasso entre peixes Neotropicais. Estudamos o desenvolvimento de Heterocharax macrolepis, espécie de Heterocharacinae cujos exemplares adultos provenientes do aquarismo foram mantidos e reproduzidos entre $23-24^{\circ} \mathrm{C}$. Uma série de desenvolvimento de 51 exemplares foi preservada, medindo entre 3,2 $\mathrm{mm}$ de comprimento da notocorda e 18,6 mm de comprimento padrão, incluindo os primeiros 73 dias pós-eclosão. Descreveram-se detalhadamente os principais aspectos morfológicos, enfatizando características úteis na identificação de larvas de H. macrolepis (i.e., surgimento do espinho do préopérculo, desenvolvimento do pseudotímpano). Comparamos H. macrolepis com fotografias de larvas vivas de Gnathocharax steindachneri, recentemente incluída em Heterocharacinae. Ambas espécies possuem saco vitelínico com pequena projeção arredondada póstero-ventral. Ainda que a informação não esteja disponível para os táxons pertinentes, o distinto formato do saco vitelínico em outras linhagens de Characiformes pode indicar que esta forma do saco vitelínico peculiar represente sinapomorfia adicional de Heterocharacini.

Key words: Early life history, Morphology, Pseudotympanum, Synapomorphy, Systematics.

\section{Introduction}

The Neotropical region houses the largest diversity of freshwater fishes on the planet (e.g., Reis et al., 2003), but knowledge on their early life history is largely incomplete, and very little has been published regarding the morphological development of juveniles into their more known adult forms. Moreover, several species are barely discernible even as adults, not to mention their often morphologically different larval forms (e.g., Kendall Jr. et al., 1984; Nakatani et al., 2001; Ponton \& Mérigoux, 2001).

${ }^{1}$ Departamento de Biologia, Universidade Federal de São Carlos - câmpus Sorocaba. Rodovia João Leme dos Santos (SP-264), Km 110, Bairro do Itinga, 18052-780 Sorocaba, SP, Brazil.gmattox@ufscar.br ${ }^{2}$ Bentheimer Straße 21, 30539 Hannover, Germany. dr.mhoffmann@web.de

${ }^{3}$ Schniggenkamp 24, 38299 Salzgitter, Germany. peter.salmler@web.de 
The difficulty in connecting larvae and juveniles to their adult stages imposes a further obstacle in the understanding of biological and ecological processes involving the early life history of these fishes (Nakatani et al., 2001). According to these authors, the study of eggs and larvae are crucial not only to better understand the biology and systematics of the studied species, but also to provide useful tools for environmental assessments regarding detection of fish stocks, identification of reproductive and hatching areas, fisheries management, among other issues in which the ichthyoplankton plays a key role. In addition to the importance in connecting early life forms and adult stages with its consequences to taxonomy and environmental sciences, the study of developing fish larvae can also yield morphological characters informative to phylogenetic relationships of different taxa (e.g., Cohen, 1984; Kendall Jr. et al., 1984; Fuiman, 1984; Britz et al., 1995; Britz, 1997, 2004; Britz \& Johnson, 2005, 2012; Johnson \& Britz, 2005; Fraser et al., 2012; Carvalho et al., 2013).

In the context of the great diversity of fishes in the Neotropical region, knowledge of larval fishes from South and Central America is still insipient (Sousa \& Severi, 2002) and generally restricted to sparse information in the literature (Ponton \& Mérigoux, 2001). There are two landmarks in the study of Neotropical larval fishes: an important contribution focusing on the eggs and larval fishes of taxa mainly from the Paraná basin (Nakatani et al., 2001) which gathers information on all lineages of teleosts sampled in their study, and the comprehensive study of larval fishes in French Guyana carried out by Ponton \& Mérigoux (2001). The remaining information on freshwater Neotropical larval fishes are scattered in separate papers often dealing with a single or a few species. These include studies on clupeiforms (e.g., Severi \& Verani, 2006; Silva et al., 2010), siluriforms (e.g., Chacon, 1975; Godinho et al., 1978; Oldani, 1983a; Kossowski \& Madrid, 1991; Cardoso et al., 1995; Sanches et al., 1999; Luz et al., 2001; Godinho et al., 2003; Lundberg et al., 2004; Feiden et al., 2005; Marques et al., 2008; Oliveira et al., 2008; Amorim et al., 2009; Faustino et al., 2010; Perini et al., 2010; Rodrigues-Galdino et al., 2010; Buzollo et al., 2011; Fuller, 2012; Honji et al., 2012; Nogueira et al., 2012; Weber et al., 2012), gymnotiforms (e.g., Kirschbaum \& Schugardt, 2002) and perciforms (e.g., Prokes et al., 1987; Pena et al., 1988; Nakatani et al., 1997; Korzelecka-Orkisz et al., 2012), besides the Characiformes. More specifically within the latter order, most studies have focused on representatives of the Anostomidae (Godinho et al., 2003), Curimatidae (Araújo Lima, 1991; Perini et al., 2013), Cynodontidae (Sousa \& Severi, 2002), Erythrinidae (Matkovic \& Pisanó, 1989; Gomes et al., 2007; Bialetzki et al., 2008; Maciel et al., 2009; Gomes et al., 2010), Lebiasinidae (Taguti et al., 2009), Parodontidae (Bialetzki et al., 1998), Prochilodontidae (Araújo Lima, 1985; Godinho et al., 2003; Ninhaus-Silveira et al., 2006), Serrasalmidae (Oldani, 1983b;
Araújo Lima et al., 1993; Ribeiro et al., 1995; Cavicchioli et al., 1997), in addition to a few Characidae (Santos \& Godinho, 2002; Godinho et al., 2003; Alexandre et al., 2009; Faustino et al., 2011; Gomes et al., 2011; Oliveira et al., 2012; Walter, 2012; Weber et al., 2013; Nogueira et al., 2014).).

Heterocharax macrolepis (Fig. 1) is a diminute characid that occurs in the Amazonas, Essequibo and Orinoco basins (Toledo-Piza, 2000) and was placed by Géry (1966) in a tribe, the Heterocharacini, that later was included in the Characinae (e.g., Géry, 1977; Lucena, 1998; Lucena \& Menezes, 2003). More recently, Mirande $(2009 ; 2010)$ and Mattox \& ToledoPiza (2012) split this subfamily in a more restricted Characinae and the distantly related Heterocharacinae, and the latter authors included in the Heterocharacinae the diminute genera Heterocharax, Hoplocharax, Gnathocharax, Lonchogenys, and Priocharax (= tribe Heterocharacini) (Fig. 2), in addition to Roestes and Gilbertolus in a separate tribe (Roestini). The Heterocharacinae as defined by Mattox \& Toledo-Piza (2012) was supported by seven non-ambiguous synapomorphies, one of which exclusive of the subfamily, and the less inclusive Heterocharacini was diagnosed by seven non-ambiguous synapomorphies, one of them exclusive of the tribe. None of the heterocharacines have been the focus of developmental studies, and moreover, juvenile specimens are often difficult to identify as their young are similar to each other. Hence, this paper aims at describing the ontogenetic development of Heterocharax macrolepis, emphasizing on characters useful for the identification of its early life stages, and compare the form of its yolk sac to Gnathocharax steindachneri, discussing a putative additional synapomorphy for the Heterocharacini.

\section{Material and Methods}

Specimens of Heterocharax macrolepis were obtained from the aquarium trade as a by catch to Hyphessobrycon bentosi. Only two specimens were available, a male with 44 $\mathrm{mm}$ Total Length (TL) and a female with $50 \mathrm{~mm}$ TL. The

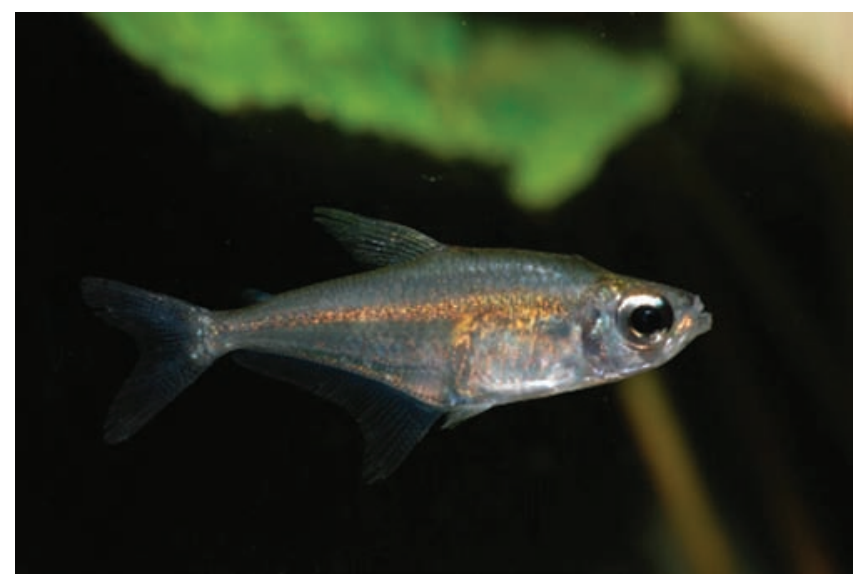

Fig. 1. Heterocharax macrolepis, live specimen photographed in a tank, not preserved. 
fish were kept in soft, slightly acid water (hardness $250 \mu \mathrm{S} /$ $\mathrm{cm}, \mathrm{pH}$ 6.0-6.5) and were fed live nauplii of brine shrimp and cut sludge worms, live or frozen small daphnia and cyclops, along with dry commercial food. They spawned repeated times in a spawning aquarium of $45 \mathrm{~L}$. The aquarium was warmed $\left(24-26^{\circ} \mathrm{C}\right)$, filtered and had a special prevention-net for the eggs. Fry was first fed paramecia and after 1-2 days they were nourished with fresh hatched Artemia salina.

The living fish were photographed with a Nikon D80 with macro lenses (Sigma $90 \mathrm{~mm}$, lens aperture 9,1/125 sec.) in a special aquarium for photography with separated $5 \mathrm{~cm}$ space in the front. The flashlight came oblique from the top and there was an additional light $(150 \mathrm{~W})$ especially for the front. Photos of live specimens in the first stages were made with the same camera connected with a special adapter to an Euromex light microscope, magnified 24-times.

The preserved series is composed of 51 specimens (BMNH 2013.10.15.1-51, 34 whole alcohol specimens and 17 cleared and stained) covering approximately the first 73 days posthatching. They were preserved in 16 batches based on date of preservation. Three or four specimens (up to batch 9), and two specimens (from batch 10 onwards) were preserved in $100 \%$ alcohol approximately every four days after hatching (up to batch 9) and every seven days post-hatching (from batch 10 onwards). Given that our series had a limited number of specimens available, we chose to sample specimens with a broader interval between days to ensure we would have at least a few specimens in later stages. Due to this limitation, we were also not able to preserve any eggs. Specimens were then fixed in buffered formalin for 48 hours and transferred to $70 \%$ alcohol, where they were permanently preserved. For the purpose of this study, we separated the specimens according to overall similarities into nine stages, taking into consideration characters used by Balon (1984) to define key ontogenetic stages. Some of the stages include specimens from more than one batch. We described the main features of specimens in these nine stages regarding their external morphology (i.e., development of fins, colour pattern, number of myomeres), aiming at the diagnostic characters of the Heterocharacini according to Mattox \& Toledo-Piza (2012).

Measurements were taken with the aid of a ruler attached to the microscope lens. Specimens were measured along their notochord length (NL) for pre-flexion and flexion larvae and their standard length (SL) for post-flexion and juvenile specimens (i.e., larger than $6.4 \mathrm{~mm} \mathrm{SL}$ ), following the terminology adopted by Kendall Jr. (1984). Seventeen

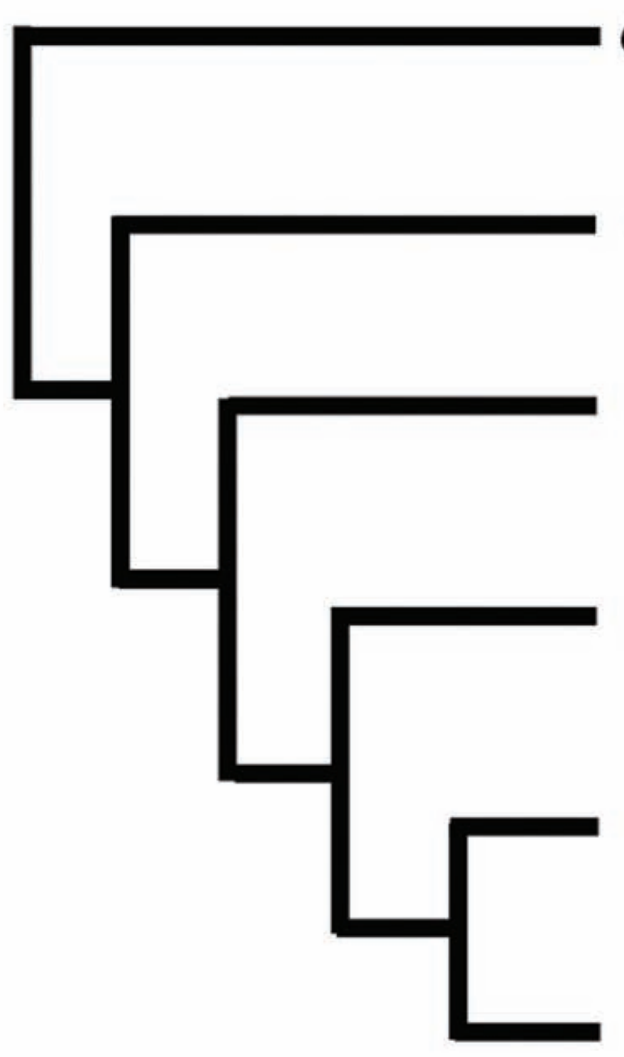

Gnathocharax steindachneri

Lonchogenys ilisha

Hoplocharax goethei

Heterocharax leptogrammus

Heterocharax virgulatus

Heterocharax macrolepis
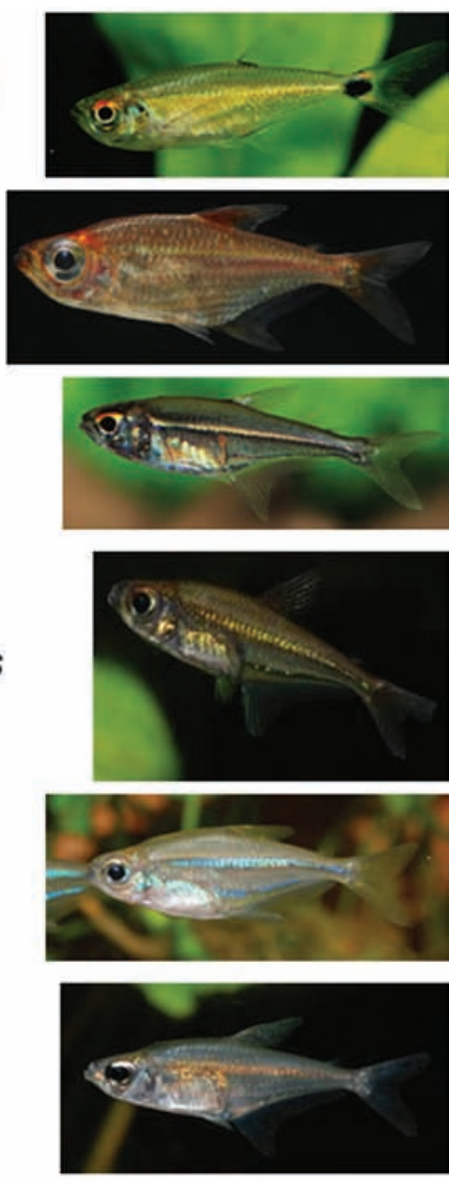

Fig. 2. Phylogenetic relationships within the tribe Heterocharacini excluding Priocharax, modified from Mattox \& Toledo-Piza (2012). 


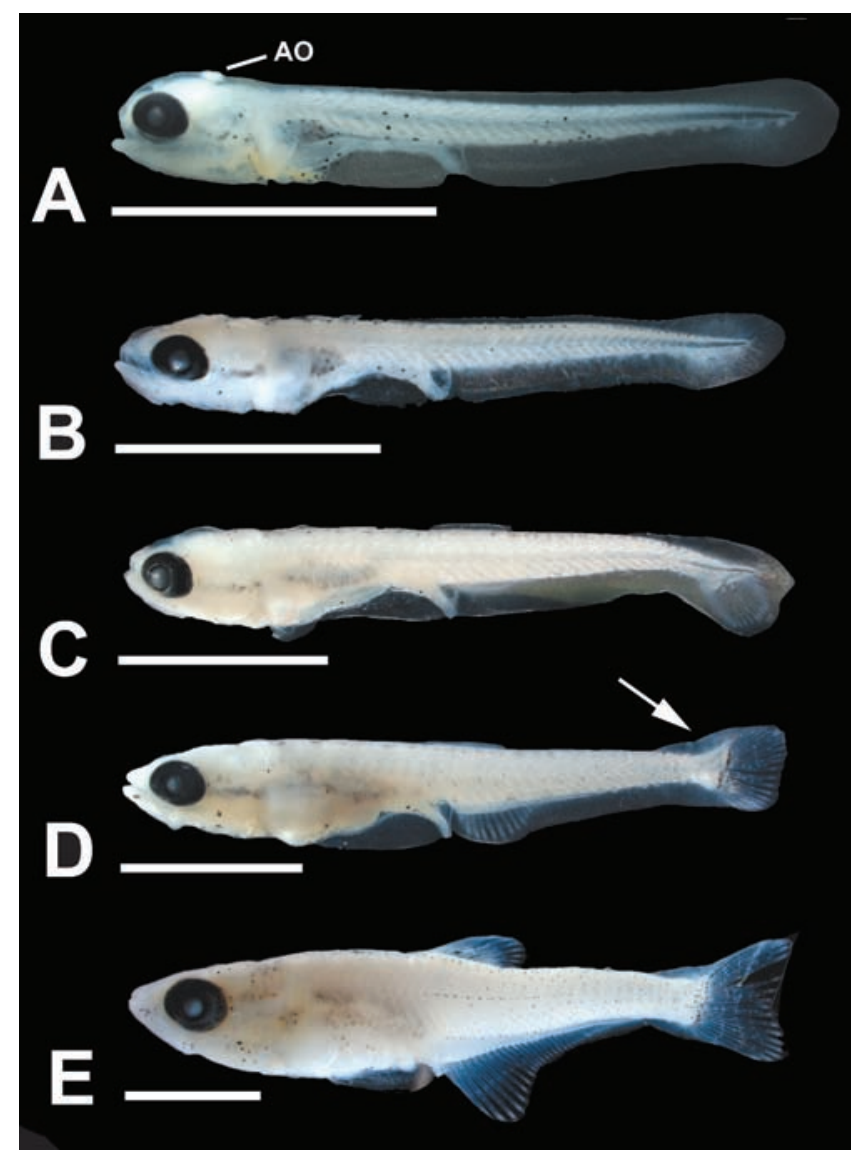

Fig. 3. Larvae and juveniles of Heterocharax macrolepis, lateral view. A: 3.9 $\mathrm{mm} \mathrm{NL}$; B: $4.7 \mathrm{~mm} \mathrm{NL}$; $: 5.7 \mathrm{~mm} \mathrm{NL}$; $6.9 \mathrm{~mm} \mathrm{SL}$; E: $7.9 \mathrm{~mm} \mathrm{SL}$. AO: Attachment organ. Arrow indicates inflexed notochord. Scale bar: $2 \mathrm{~mm}$.

specimens ranging from $3.2 \mathrm{~mm}$ NL to $18.5 \mathrm{~mm}$ SL were cleared and stained according to Taylor \& Van Dyke (1985) to aid in the observations. Counts of fin rays refer to total number of rays. Counts of caudal-fin rays refer to dorsal + ventral lobes, whenever applicable. Specimens were photographed with a digital camera associated with a Zeiss Discovery V20 Stereomicroscope using the Z-Stack option. We did not include photographs of all described stages due to economy of space. In addition, our data was compared to photographs of live and newly hatched specimens of Gnathocharax steindachneri obtained by two of us (M. \& P. Hoffmann) over two decades ago, which were not preserved.

\section{Results}

Heterocharax macrolepis scatters brown to black eggs in the night or early in the morning. Up to 300 eggs were observed after pairing has finished. Fry hatched in a separate small $250 \mathrm{ml}$ plastic box with same water after 30-36h, swam and had air in the swimbladder after 5-6 days and began to eat after 6-7 days.

Stage $1(\mathrm{n}=4$, five to eight days post-hatching, 3.9-4.4 $\mathrm{mm}$ NL): Pre-flexion larvae. Myomeres along body 32-34.

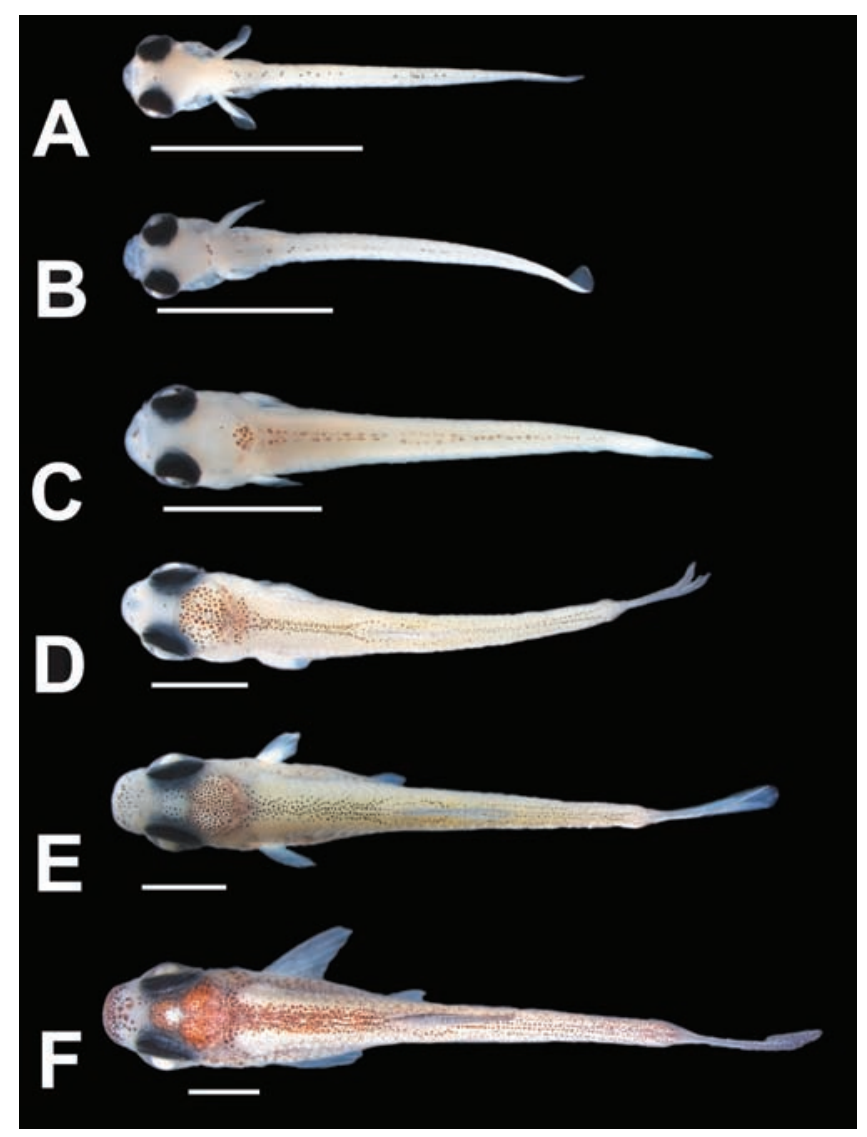

Fig. 4. Larvae and juveniles of Heterocharax macrolepis, dorsal view. A: 3.9 mm NL; B: $5.1 \mathrm{~mm} \mathrm{NL}$; C: $7.3 \mathrm{~mm} \mathrm{SL}$;: $10.2 \mathrm{~mm} \mathrm{SL}$; E: $13.6 \mathrm{~mm} \mathrm{SL}$; F: $16.2 \mathrm{~mm}$ SL. Scale bar: $2 \mathrm{~mm}$.

Attachment organ present as single round structure on dorsal surface of head, approximately at vertical through anterior portion of opercle (Fig. 3A). Yolk-sac almost entirely absorbed. No fin rays. Dorsal and ventral finfolds well developed and continuous around posterior end of body. Thin line of deep melanophores radiating posteriorly from the eye to posterior portion of head. Few melanophores around pectoral-fin base and some melanophores scattered on lateral and ventral surfaces of regressing yolk-sac. Lateral surface of body with few melanophores at vertical through posterior end of intestine forming anterior patch of melanophores, and posterior small patch of melanophores, approximately on anterior one-third posterior to anus. Dorsal margin of body with anterior line of melanophores from vertical through pectoral-fin origin to vertical through anus, and posterior line of melanophores from vertical at approximately posterior border of posterior patch of lateral melanophores to posterior tip of notochord (Fig. 4A).

Stage $2(\mathrm{n}=7,11-17$ days post-hatching, 4.7-5.4 $\mathrm{mm} \mathrm{NL}$ ): Flexion larvae. Myomeres along body 31-34. Attachment organ completely reabsorbed. Yolk-sac almost entirely absorbed. Condensed tissue ventral to notochord on region of caudal-fin rays, lepidotrichia present on caudal fin of largest specimen, other fin rays absent (Fig. 3B). Dorsal and ventral 
finfolds well developed and continuous around posterior end of body, with dorsal finfold less deep than previous stages. Colour pattern similar to previous stage, but with more melanophores on lateral of yolk-sac, and melanophores deep in body covering lateral and ventral surfaces of swim-bladder. Transversal line of melanophores across dorsal surface of head at vertical through posterior portion of skull (Fig. 4B). Dorsal midline of body with continuous line of melanophores from posterior portion of head to approximately posterior tip of notochord. Transverse line of melanophores on ventral surface of body, at vertical immediately anterior to cleithrum.

Stage $3(n=3,17-20$ days post-hatching, 5.7-6.3 mm NL): Flexion larvae. Myomeres along body 34 . Yolk-sac completely absorbed. Caudal-fin rays 9+7-9 rays, posterior margin of caudal fin rounded. Anal fin with 5-7 short fin rays on anterior portion of post-anal finfold. Other fin rays absent (Fig. 3C). Condensed tissue on anterior portion of dorsal finfold. Dorsal finfold less developed, starting at vertical through anus. Ground coloration of body more white, covering parts of dark colour pattern (i.e., black stripe of melanophores posterior to eye and melanophores lateral and ventral to swim-bladder barely visible).

Stage $4(\mathrm{n}=5,20-23$ days post-hatching, 6.4-7.3 $\mathrm{mm} \mathrm{SL})$ : Post-flexion larvae. Myomeres along body 32-33. Smallest specimen with anal-fin rays 8 , caudal fin damaged. Larger specimens with caudal-fin rays $9+8$ or $9+9$, most of which segmented, and anal-fin rays 11-15 (Fig. 3D). Five to six short lepidotrichia on dorsal fin of largest specimen. Anal fin with rounded distal profile, reaching more ventrally than remaining post-anal finfold. All specimens with dorsal finfold split in anterior portion where dorsal fin will develop and posterior portion anterior do caudal fin. Posterior margin of caudal fin straight, with slight curve along its midlength. All two specimens with thin vertical line of melanophores laterally along caudal-fin base and some melanophores along posterior portion of branchiostegal rays. Largest specimen with scattered melanophores on lateral surface of caudal fin. Dorsal surface of head with patch of melanophores continuous to line of paired melanophores along dorsal midline of body. Dorsal paired line of melanophores as single line of melanophores from vertical through anus to near tip of notochord (Fig. 4C). All specimens with melanophores on middle of lower jaw and largest specimen with many melanophores along posterior portion of branchiostegal rays.

Stage $5(\mathrm{n}=6,26-29$ days post-hatching, 7.4-9.2 $\mathrm{mm} \mathrm{SL})$ : Post-flexion larvae. Myomeres along body 33-35. Anal-fin rays 20-25. Caudal-fin slightly bifurcated, caudal-fin rays 9+9 or 10+9. Dorsal-fin rays 5-6, with round distal profile of dorsal fin (Fig. 3E). Larger specimens with dorsal fin well developed, with 9 rays. Most specimens with well developed dorsal and anal fins, but with remains of dorsal and ventral finfolds still present. Pelvic-fin buds lateral to pre-anal finfold anterior to anus. Dorsal finfold restricted to portion of dorsal fin, and small

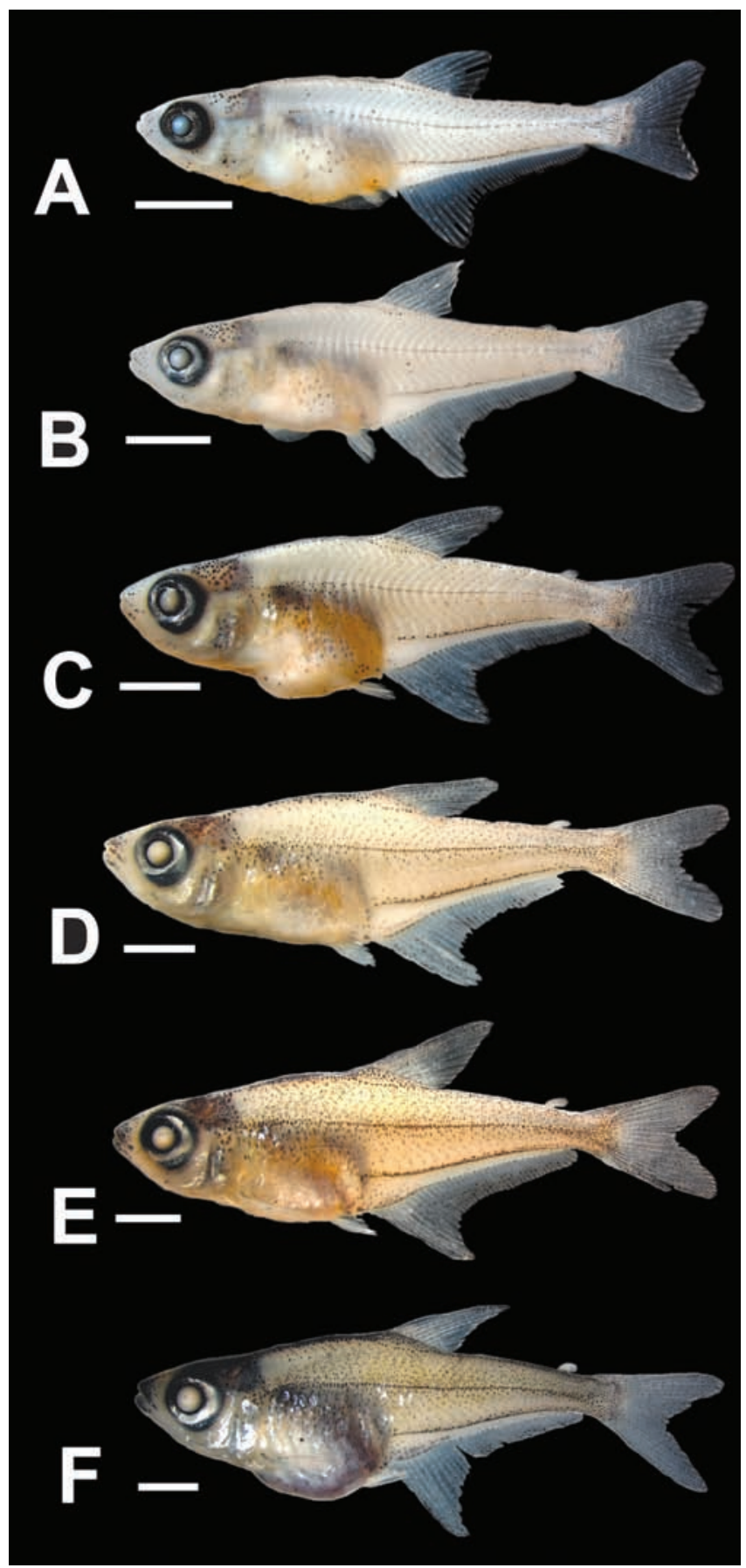

Fig. 5. Larvae of Heterocharax macrolepis, lateral view. A: $9.3 \mathrm{~mm}$ SL; B: $10.2 \mathrm{~mm} \mathrm{SL}$; : $13.6 \mathrm{~mm} \mathrm{SL}$; D: $15.5 \mathrm{~mm} \mathrm{SL}$; E: $16.2 \mathrm{~mm} \mathrm{SL}$; F: $18.6 \mathrm{~mm}$ SL. Scale bar: $2 \mathrm{~mm}$.

flap of skin on developing adipose fin region. Pre-anal finfold present but small, with line of melanophores along its base. Post-anal finfold composed of developing anal fin anteriorly and a narrower finfold gradually less deep posteriorly. Thin lines of three to four superficial melanophores along myosepta posterior to anus, and thin line of melanophores along the lateral midline of body from vertical through anus to end of caudal peduncle. Thin line of melanophores along anal-fin 
base, slightly detached from fin base anteriorly. Other thin and inconspicuous line of melanophores along base of anal-fin rays, approximately from vertical through ninth ray to end of caudal peduncle. Head with melanophores around eye, on opercle, along branchiostegal rays and membranes and dorsal surface of head. Largest specimen with conspicuous line of superficial melanophores along lateral midline of body from vertical through pelvic-fin buds to posterior portion of caudal peduncle, as well as conspicuous line of melanophores along anal-fin base. Thin line of melanophores on dorsal surface of head, extending anteriorly from dorsal patch of melanophores near posterior portion of skull. Scattered melanophores on lateral surface of caudal peduncle forming triangular blotch. Ventral portion of intestine with melanophores on posterior portion.

Stage $6(\mathrm{n}=2,32-39$ days post-hatching, 9.3-10.2 $\mathrm{mm} \mathrm{SL})$ : Post-flexion larvae. Myomeres along body 34-35. All finfolds completely reabsorbed, except for small pre-anal finfold. Anal-fin rays 37-39, with notch on anterior one-third. Dorsal fin rays 9-10. Caudal-fin rays $11+10$, with posterior margin bifurcated (Fig. 5A). Pelvic fin reaching distal margin of preanal finfold, with developing lepidotrichia. Pseudotympanum evident anterior to closing myomeres of body and vertical

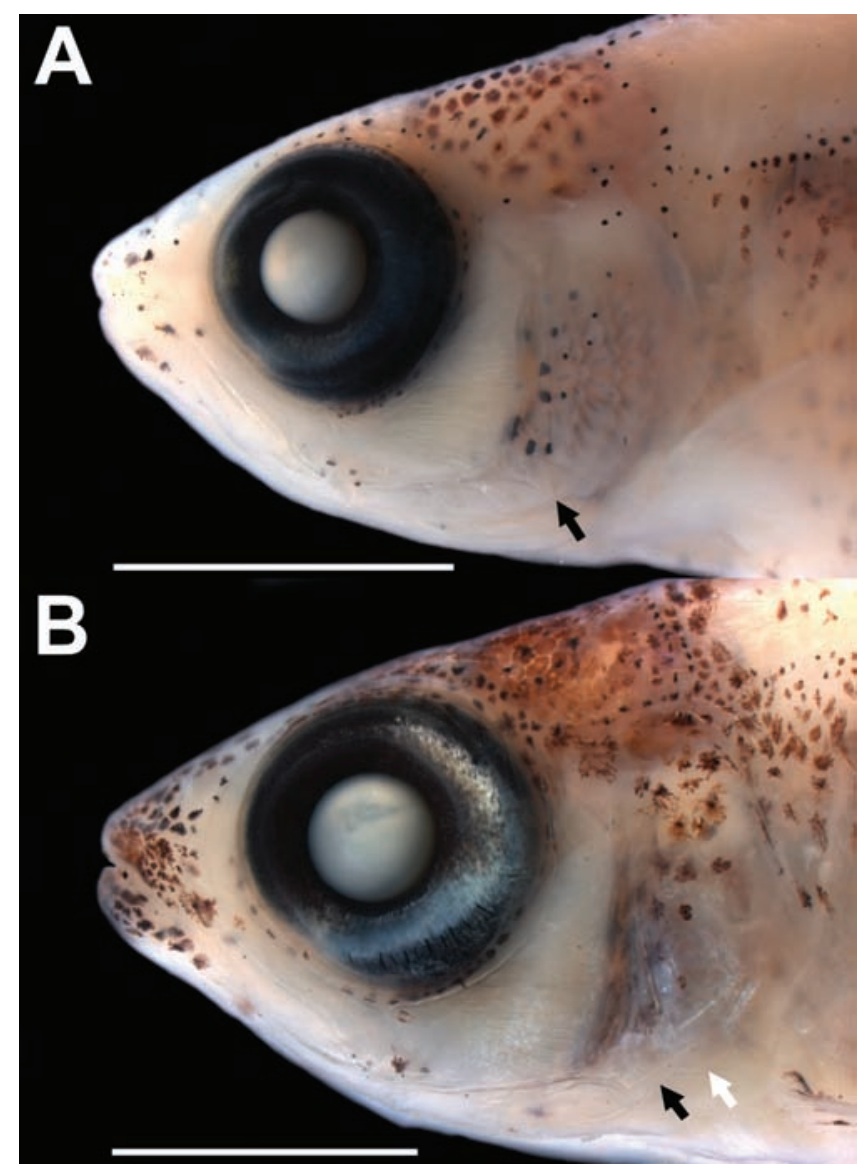

Fig. 6. Larvae of Heterocharax macrolepis, lateral view of head. A: $13.6 \mathrm{~mm}$ SL; B: $16.2 \mathrm{~mm}$ SL. Black arrows indicate posteroventral border of preopercle and white arrow indicates tip of preopercle spine in (B). Scale bar: $2 \mathrm{~mm}$. through posterior margin of pectoral-fin bud $(9.3 \mathrm{~mm} \mathrm{SL})$, more evident anterior to fifth pleural rib in largest specimen (Fig. 5B). Many melanophores on dorsal surface of head and pre-dorsal area of body. Stripe of melanophores along dorsal midline of body, extending from dorsal patch of melanophores on dorsal surface of head to dorsal-fin origin; stripe bifurcated around dorsal-fin and reunited posteriorly in single line posterior to dorsal fin (Fig. 4D). Lateral line of melanophores conspicuous along midline of body, from pseudotympanum to triangular blotch of melanophores of caudal peduncle. Conspicuous line of melanophores along anal-fin base. Dorsal, anal and caudal fins with melanophores on lateral margins. Lateral region of abdomen, especially swimbladder, with many deep melanophores. Eye with guanine silver pigment.

Stage $7(\mathrm{n}=1,46$ days post-hatching, $13.6 \mathrm{~mm} \mathrm{SL})$ : Juvenile. Myomeres along body 34. All finfolds completely reabsorbed. Adipose fin evident and free from skin. Dorsal-fin rays 11 . Anal-fin rays 39 . Caudal-fin rays $11+10$. Pectoral-fin rays 7 along ventral surface of pectoral-fin bud. Pelvic-fin rays 7. Line of melanophores along anal-fin base slightly thicker and more evident (Fig. 5C). Superficial melanophores on lateral surface of body ventral to lateral midline of body ventral to pseudotympanum. Line of melanophores along dorsolateral surface of cleithrum. Stripe of melanophores along dorsal midline of body wide and well developed between head and dorsal-fin origin (Fig. 4E). Dorsal surface of snout with patch of melanophores between nasal opening and upper jaw. Eye with guanine silver pigment.

Stage $8(n=2,53-60$ days post-hatching, 15.4-15.5 mm SL): Juvenile. Myomeres along body 34-35. Dorsal-fin rays 11 . Anal-fin rays 39 . Caudal-fin rays $11+10$. Pectoralfin rays 12 , rays extending from pectoral-fin base to distal margin of pectoral-fin membrane. Pelvic-fin rays 7. Colour pattern of head and body more conspicuous, with all stripes generally wider. Anterior portion of snout well pigmented including upper and lower jaws. Dorsal fin more pigmented anteriorly. Line along anal-fin base with superficial and deep melanophores (only superficial melanophores up to this stage). Eye, preopercle and opercle with guanine silver pigment (Fig. 5D). Preopercle spine small but evident externally. Scales evident near pectoral-fin base.

Stage $9(\mathrm{n}=2$, 67-73 days post-hatching, 16.2-18.6 $\mathrm{mm}$ SL): Juvenile. Myomeres along body 35 . All fins fully developed (Fig. 5E). Pseudotympanum fully formed and evident anterior to rib of fifth vertebra. Dorsal surface of head and pre-dorsal region of body heavily pigmented (Fig. 4F). Lines along anal-fin base (near and adjacent) continuous, with deep and superficial melanophores. Anal fin well pigmented along anterior and distal margins, dorsal fin pigmented along anterior margin and caudal fin more pigmented along dorsal and ventral margins. Preopercle and opercle with deep melanophores and superficial guanine. Guanine in eye and 
near ventral one-half of abdomen, with guanine more abundant on lateral surface of head and ventral abdominal region in largest specimen (Fig. 5F). Scales present on anterior one-half of body, approximately to the vertical through anal-fin origin, reaching slightly further posteriorly in largest specimen. Lateral line with 11-13 perforated scales, with melanophores delimiting canal dorsally and ventrally. Preopercle spine well developed (Fig. 6B).

In addition to the series of preserved specimens, we had access to photographs of live specimens of Heterocharax macrolepis covering the first two days post-hatching (Fig. 7AB). In these specimens, the yolk-sac has a peculiar shape with a posteroventrally directed round structure in addition to the larger portion of the yolk-sac core. Hence, the overall aspect of the yolk-sac in the early stages of $H$. macrolepis roughly resembles a bowling pin. This structure was not present in the older preserved specimens examined herein, most of them with their yolk-sac mostly reabsorbed. The same form of the yolksac was present in early stages of Gnathocharax steindachneri, as evidenced by similar photographs of unpreserved live fry (Fig. 7C) covering approximately two days post-hatching.

\section{Discussion}

Our study represents the first ontogenetic approach of a representative of the Heterocharacinae, a Neotropical group of generally small characids inhabiting mainly the Amazon basin. In the context of the theory of the saltatory ontogeny of Balon (1984), the key event characterizing the transition from embryo to larva is the onset of exogenous feeding. All specimens examined herein have clearly passed that threshold, although they include stages that still rely partially on their yolk sac, a feature of the embryonic period of the scheme proposed by Balon (1984). According to this author, the last embryonic phase (i.e., free embryo) includes three steps which are characterized by (i) differentiation of finfold, formation of first dermal rays of unpaired fins, development of first chondrified skeletal structures and growth of pelvic fins beyond the finfold edge; (ii) onset of photophobia, transfer to mainly branchial respiration and calcification of jaw tooth points; (iii) complete absorption of yolk, calcification of skeletal structures, rapid expansion of iridocyte distribution. In Heterocharax macrolepis, a few of these features were observed such as formation of first dermal rays of unpaired fins in stage 2, growth of pelvic fins beyond the finfold edge in stage 6 , and complete absorption of yolk in stage 3 . This shows that a number of features that precedes the onset of exogenous feeding according to Balon (1984) occurs after exogenous feeding has taken place in $H$. macrolepis.

One interesting result obtained herein is the sequence of development of the fins in Heterocharax macrolepis. According to our data, the sequence of fin development
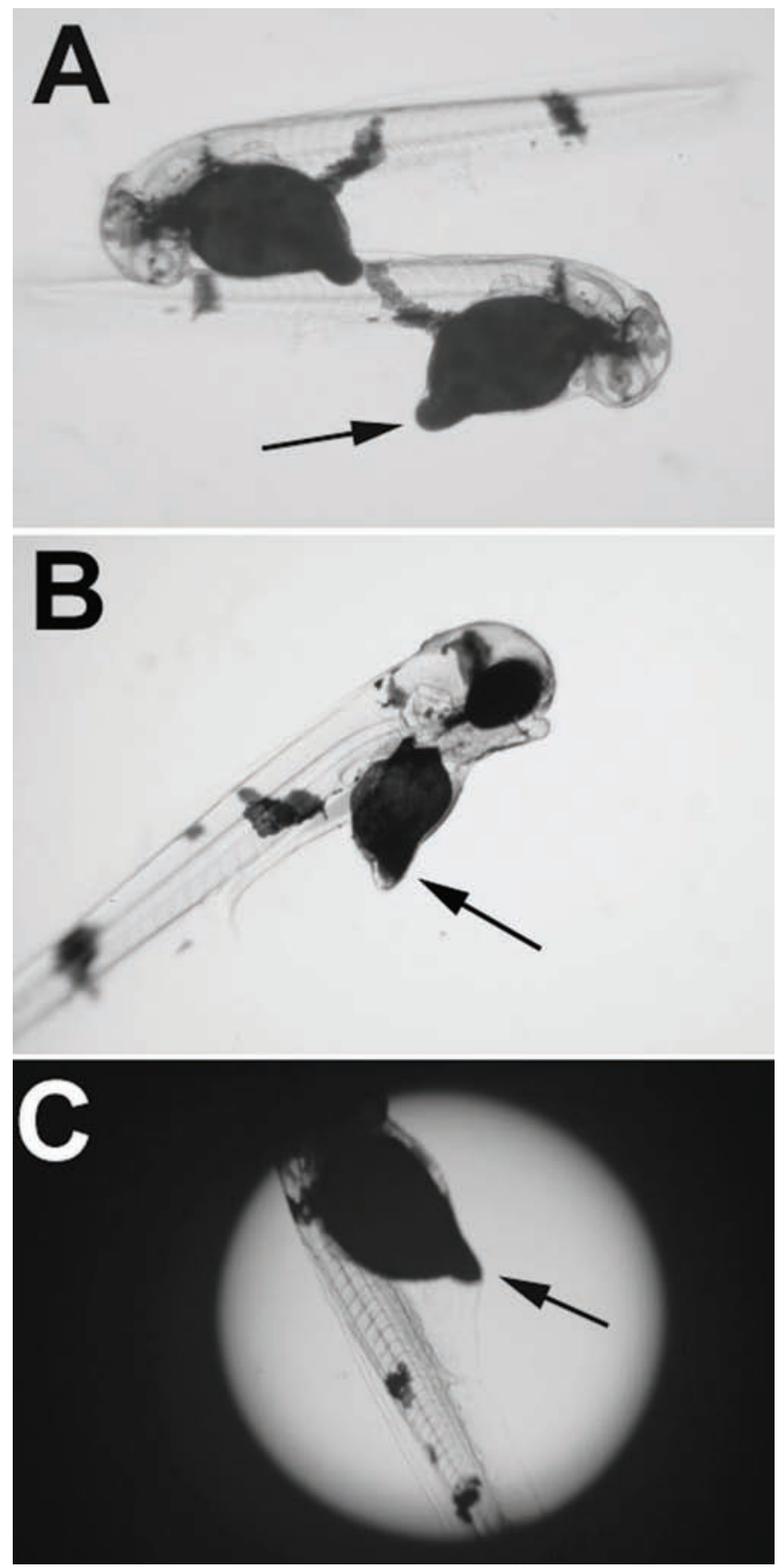

Fig. 7. Live larvae of Heterocharax macrolepis (A-B) and Gnathocharax steindachneri (C). A: approximately one day post-hatching; B: approximately three days post-hatching; C: approximately three days post-hatching. Arrows indicate posteroventral rounded projection of the yolk sac.

is caudal, anal, dorsal, pelvic, and pectoral. This slightly contrasts from all characiforms studied by Nakatani et al. (2001) who provided information for 27 of the 31 species representing seven families of the order in which the pattern of developmental sequence was caudal, dorsal, anal, pelvic and pectoral, hence showing one difference in relation to what is reported herein for $H$. macrolepis: the shift between anal and dorsal fins. Ponton \& Mérigoux (2001) examined over 34 species of Characiformes and reported a similar pattern 
of fin development for most of them (e.g., caudal, dorsal, anal, pelvic, pectoral fins). Exceptions were Acestrorhynchus falcatus and A. microlepis, Charax pauciradiatus, Poptella brevispina, and Phenacogaster megalostictus in which the anal fin preceded the dorsal fin as observed in H. macrolepis. The same pattern was described by Taguti et al. (2009) in Pyrrhulina australis. Among these species, C. pauciradiatus, $P$. megalostictus, and $H$. macrolepis were already classified in the same subfamily based on the long anal fin (e.g., Géry, 1977), a feature that might be related to the early shift of the onset of the anal-fin development. The difference on the onset of development between anal and dorsal fins reported herein is quite subtle, as both fins begin to develop at almost the same time (i.e., among cleared and stained specimens, rays of both fins are present simultaneously at $8.2 \mathrm{~mm} \mathrm{SL}$ ), similar to what was described for Rhaphiodon vulpinus (Sousa $\&$ Severi, 2002). These authors stated that due to the almost simultaneous onset of development of the dorsal and anal fins, this character might not have a significant taxonomic value. Such information is, however, so far unavailable for the majority of the Heterocharacinae and many putative related characids (e.g., Mattox \& Toledo-Piza, 2012), hence it would be interesting to investigate this feature in other representatives of the subfamily to understand whether this subtle heterochronic shift bears phylogenetic signal.

We highlighted herein the development of two putative synapomorphies of the Heterocharacinae sensu Mattox \& ToledoPiza (2012): the presence of a pseudotympanum restricted to the region anterior of the rib of the fifth vertebra and the presence of a spiniform projection on the posterior margin of the preopercle, the latter feature also interpreted as a synapomorphy of the Heterocharacinae by Mirande (2010). Both characters are useful to identify specimens of this subfamily, and in Heterocharax macrolepis they are discernible at $16.2 \mathrm{~mm} \mathrm{SL}$ and $15.8 \mathrm{~mm} \mathrm{SL}$, respectively. The ontogeny of the pseudotympanum was briefly reported for the cheirodontine Spintherobolus papilliferus by Weitzman \& Malabarba (1999) in which a large gap in the lateral musculature of the body gradually closes anteriorly, leaving the pseudotympanum restricted between ribs of fifth and sixth vertebrae, a result opposite to what was described herein for $H$. macrolepis. In the latter species, myomeres of the lateral wall of the body gradually close posteriorly and the future region of the pseudotympanum is visible at $9.3 \mathrm{~mm} \mathrm{SL}$ (Fig. 5A). At 10.2 $\mathrm{mm}$ SL, the pseudotympanum is evident anterior to the fifth pleural rib (Fig. 5B) and the gap continues to close anteriorly until the condition typical of heterocharacines is reached at 16.2 $\mathrm{mm} \mathrm{SL}$ (Fig. 5E). As for the preopercle spine, early stages of $H$. macrolepis possess the general condition of Characiformes in which the posterior margin of the preopercle lacks any projections (Fig. 6A). At $15.8 \mathrm{~mm} \mathrm{SL}$, a preopercle spine is clearly visible and constitutes an additional character useful for the identification of larvae of H. macrolepis (e.g., Fig. 6B).
A further interesting observation of the present study is the form of the yolk sac in early stages of Heterocharax macrolepis. Photographs of live specimens of $H$. macrolepis up to three days post-hatching show a distinct form of the yolk sac in which the main body of the structure is rounded and bears a smaller rounded projection directed posteroventrally, resulting in the shape similar to a bowling pin (Fig. 7A-B). The exact same form of the yolk sac is visible in early larval stages of another heterocharacine, Gnathocharax steindachneri (Fig. 7C). Virta \& Cooper (2009) carried out a comprehensive study on the form of the yolk sac in 462 species of 35 orders of Actinopterygii, including seven species of the Characiformes. They organized the yolk sac into eight morphological categories and interpreted them in the phylogenetic context. None of them resemble the unique shape of the yolk sac described herein. This unique shape of the yolk sac was not reported in any of the many representatives of the Characiformes available in the literature (e.g., Nakatani et al., 2001; Ponton \& Mérigoux, 2001; most of the references on ontogeny of characiforms cited above) and could hence constitute an additional synapomorphy for the clade comprising at least Heterocharax and Gnathocharax (the Heterocharacini of Mattox \& Toledo-Piza, 2012). This hypothesis, however, can only be properly tested when more developmental series of representatives of the Heterocharacini are available, and it is herein proposed only as a putative additional character for this clade.

We hope that this work will stimulate further studies involving the morphological development of other characiforms, and Neotropical fishes in general, as ontogenetic approaches to the richest ichthyofauna in the world are still scarce in the literature albeit their important role in taxonomy and systematics of fishes (e.g., Cohen, 1984; Kendall Jr., et al., 1984; Fuiman, 1984; Nakatani et al., 2001; Ponton \& Mérigoux, 2001). Moreover, further establishment of partnerships between ichthyologists and aquarists can be useful in understanding the development of Neotropical fishes, uniting different sources of knowledge towards the same objective.

\section{Acknowledgments}

The authors are deeply grateful to Ralf Britz (NHM, London) for encouragement, providing literature and commenting on initial drafts of the manuscript. This study was developed at the Department of Zoology, Natural History Museum, London and Instituto de Biociências, Universidade de São Paulo, which provided work space and access to facilities. Thanks are also due to Mônica Toledo-Piza (IBUSP) for her guidance and support to the first author. Previous versions of the manuscript greatly benefitted from suggestions by Kevin Conway and an anonymous reviewer. G. M. T. M. 
was funded by a post-doctoral fellowship (FAPESP - Proc. 2010/50941-8) and an international internship grant (FAPESP - Proc 2012/01075-1).

\section{Literature Cited}

Alexandre, J. S., A. Ninhaus-Silveira, R. Veríssimo-Silveira, H. Buzollo, J. A. Senhorini \& M. P. Chaguri. 2009. Structural analysis of the embryonic development in Brycon cephalus (Günther, 1869). Zygote, 18: 173-183.

Amorim, M. P., B. V. C. Gomes, Y. S. Martins, Y. Sato, E. Rizzo \& N. Bazzoli. 2009. Early development of the silver catfish Rhamdia quelen (Quoy \& Gaimard, 1824) (Pisces: Heptapteridae) from the São Francisco River Basin, Brazil. Aquaculture Research, 40: $172-180$

Araújo Lima, C. A. R. M. 1985. Aspectos biológicos de peixes amazônicos. V. Desenvolvimento larval do jaraqui-escama grossa, Semaprochilodus insignis (Characiformes, Pisces) da Amazônia Central. Revista Brasileira de Biologia, 45: 423-431.

Araújo Lima, C. A. R. M. 1991. A larva da branquinha comum, Potamorhina latior (Curimatidae, Pisces) da Amazônia Central. Revista Brasileira de Biologia, 51: 45-56.

Araújo Lima, C. A. R. M., A. L. Kirovsky \& A. G. Marca. 1993. As larvas dos pacus, Mylossoma spp. (Teleostei; Characidae), da Amazônia Central. Revista Brasileira de Biologia, 53: 591-600.

Balon, E. K. 1984. Reflections on some decisive events in the early life of fishes. Transactions of the American Fisheries Society, 113: 178-185.

Bialetzki, A., K. Nakatani, P. V. Sanches, G. Baumgartner, M. C. Makrakis \& T. L. Taguti. 2008. Desenvolvimento inicial de Hoplias aff. malabaricus (Bloch, 1794) (Osteichthyes, Erythrinidae) da planície alagável do alto rio Paraná, Brasil. Acta Scientiarum, Biological Sciences, 30: 141-149.

Bialetzki, A., P. V. Sanches, G. Baumgartner \& K. Nakatani. 1998. Caracterização morfológica e distribuição temporal de larvas e juvenis de Apareiodon affinis (Steindachner) (Osteichthyes, Parodontidae) no alto Rio Paraná, Paraná. Revista Brasileira de Zoologia, 15: 1037-1047.

Britz, R. 1997. Egg surface structure and larval cement glands in nandid and badid fishes with remarks on phylogeny and biogeography. American Museum Novitates, 3195: 1-17.

Britz, R. 2004. Egg structure and larval development of Pantodon buchholzi (Teleostei: Osteoglossomorpha), with a review of data on reproduction and early life history in other osteoglossomorphs. Ichthyological Exploration of Freshwaters, 15: 209-224.

Britz, R. \& G. D. Johnson. 2005. Leis' conundrum: homology of the clavus of the ocean sunfishes. 1. Ontogeny of the median fins and axial skeleton of Monotrete leiurus (Teleostei, Tetraodontiformes, Tetraodontidae). Journal of Morphology, 266: 1-10.

Britz, R. \& G. D. Johnson. 2012. Ontogeny and homology of the skeletal elements that form the sucking disc of remoras (Teleostei, Echeneoidei, Echeneidae). Journal of Morphology, 273: 1353-1366.

Britz, R., M. Kokoscha \& R. Riehl. 1995. The anabantoid genera Ctenops, Luciocephalus, Parasphaerichthys, and Sphaerichthys as a monophyletic group: evidence from egg surface structure and reproductive behaviour. Japanese Journal of Ichthyology, 42: 71-79.

Buzollo, H., R. Veríssimo-Silveira, I. R. Oliveira-Almeida, J. S. Alexandre, H. T. Okuda \& A. Ninhaus-Silveira. 2011. Structural analysis of the Pimelodus maculatus (Lacépède,
1803 ) embryogenesis (Siluriformes: Pimelodidae). Neotropical Ichthyology, 9: 601-616.

Cardoso, E. L., M. S. D. Alves, R. M. A. Ferreira \& H. P. Godinho. 1995. Embryogenesis of the neotropical freshwater Siluriforme Pseudoplatystoma coruscans. Aquatic Living Resources, 8: 343-346.

Carvalho, M., F. A. Bockmann \& M. R. Carvalho. 2013. Homology of the fifth epibranchial and accessory elements of the ceratobranchials among Gnathostomes: insights from the development of ostariophysans. PLoS One 8: e62389.

Cavicchioli, M., K. Nakatani \& O. A. Shibatta. 1997. Morphometric variation of larvae and juveniles of the piranhas Serrasalmus spilopleura and S. marginatus (Characidae: Serrasalminae) of the Paraná basin, Brazil. Ichthyological Exploration of Freshwaters 8: 97-106.

Chacon, J. 1975. Embryonic and early larval stages of cangati catfish, Trachycorystes galeatus Linnaeus, 1756, at the Amanari fish culture station, Maranguape, Ceará, Brazil. Revista Brasileira de Biologia, 35: 737-744.

Cohen, D. M. 1984. Ontogeny, systematics, and phylogeny. Pp. 7-11. In: Moser, H. G., W. J. Richards, D. M. Cohen, M. P. Fahay, A. W. Kendall Jr. \& S. L. Richardson (Eds.). Ontogeny and systematics of fishes. Special Publication $n^{\circ} 1$ - American Society of Ichthyologists and Herpetologists. New York.

Faustino, F., L. S. O. Nakaghi, C. Marques, L. N. Ganeco \& L. C. Makino. 2010. Structural and ultrastructural characterization of the embryonic development of Pseudoplatystoma spp. hybrids. International Journal of Developmental Biology, 54: 723-730.

Faustino, F., L. S. O. Nakaghi \& E. Neumann. 2011. Brycon gouldingi (Teleostei, Characidae): aspects of the embryonic development in a new fish species with aquaculture potential. Zygote, 19: 351-363.

Feiden, A., C. Hayashi, W. R. Boscolo \& A. Signor. 2005. Desenvolvimento do surubim do Iguaçu (Steindachneridion sp., Garavello (1991)) (Siluroidei: Pimelodidae) em ambiente escuro durante a fase inicial, alimentado com diferentes dietas. Semina, Ciências Agrárias, 26: 109-116.

Fraser, G. J., R. Britz, A. Hall, Z. Johanson \& M. M. Smith. 2012. Replacing the first-generation dentition in pufferfish with a unique beak. Proceedings of the National Academy of Sciences, USA, 109: 8179-8184.

Fuiman, L. A. 1984. Ostariophysi: development and relationships. Pp.126-137. In: Moser, H. G., W. J. Richards, D. M. Cohen, M. P. Fahay, A. W. Kendall Jr. \& S. L. Richardson (Eds.). Ontogeny and systematics of fishes. Special Publication $n^{\circ}$ 1 - American Society of Ichthyologists and Herpetologists. New York.

Fuller, I. A. M. 2012. Breeding Corydoradinae catfish. Second Edition. Kidderminster, GB, Ian Fuller Enterprises.

Géry, J. 1966. Hoplocharax goethei, a new genus and species of South American characoid fishes, with a review of the sub-tribe Heterocharacini. Ichthyologica, 38: 281-296.

Géry, J. 1977. Characoids of the world. Neptune City, NJ, THF Publications.

Godinho, H. P., N. A. Fenerich \& M. Y. Narahara. 1978. Desenvolvimento embrionário e larval de Rhamdia hilarii (Valenciennes, 1840) (Siluriformes, Pimelodidae). Revista Brasileira de Biologia, 38: 151-156.

Godinho, H. P., J. E. Santos \& Y. Sato. 2003. Ontogênese larval de cinco espécies de peixes do São Francisco. Pp. 133-148. In: Godinho, H. P. \& Y. Sato (Orgs.). Água, peixes e pescadores do São Francisco de Minas Gerais. Belo Horizonte, MG, PUC Minas. 
Gomes, M. L. M., S. L. P. Matta, V. A. Araújo, G. M. F. Silva \& A. A. Zacaro. 2010. Larval ontogeny and morphology of giant trahira Hoplias lacerdae. Journal of Fish Biology, 76: 852-861.

Gomes, R. Z., Y. Sato, E. Rizzo \& N. Bazzoli. 2011. Early development of Brycon orthotaenia (Pisces: Characidae). Zygote, 21: 11-20.

Gomes, B. V. C., R. S. Scarpelli, F. P. Arantes, Y. Sato, N. Bazzoli \& E. Rizzo. 2007. Comparative oocyte morphology and early development in three species of trahiras from the São Francisco River basin, Brazil. Journal of Fish Biology, 70: 1412-1429.

Honji, R. M., C. E. Tolussi, P. H. Mello, D. Caneppele \& R. G. Moreira. 2012. Embryonic development and larval stages of Steindachneridion parahybae (Siluriformes: Pimelodidae) implications for the conservation and rearing of this endangered Neotropical species. Neotropical Ichthyology, 10: 313-327.

Johnson, G. D. \& R. Britz. 2005. Leis' conundrum: homology of the clavus of the ocean sunfishes. 2. Ontogeny of the median fins and axial skeleton of Ranzania laevis (Teleostei, Tetraodontiformes, Molidae). Journal of Morphology, 266: 11-21.

Kendall Jr., A. W., E. H. Ahlstrom \& H. G. Moser. 1984. Early life history stages of fishes and their characters. Pp. 11-22. In: Moser, H. G., W. J. Richards, D. M. Cohen, M. P. Fahay, A. W. Kendall Jr. \& S. L. Richardson (Eds.). Ontogeny and systematics of fishes. Special Publication $\mathrm{n}^{\mathrm{o}} 1$ - American Society of Ichthyologists and Herpetologists. New York.

Kirschbaum, F. \& C. Schugardt. 2002. Reproductive strategies and developmental aspects in mormyrid and gymnotiform fishes. Journal of Physiology - Paris, 96: 557-566.

Korzelecka-Orkisz, A., Z. Szalast, D. Pawlos, I. Smaruj, A. Tañski, J. Szulc \& K. Formicki. 2012. Early ontogenesis of the angelfish, Pterophyllum scalare Schultze, 1823 (Cichlidae). Neotropical Ichthyology, 10: 567-576.

Kossowski, C. \& F. Madrid. 1991. Observationes de los estadios embrionario y larval des bragre rayado cabezon Pseudoplatystoma fasciatum (Linnaeus, 1766) (Pisces, Siluriformes). Biollania, 8: 9-15.

Lucena, C. A. S. 1998. Relações filogenéticas e definição do gênero Roeboides Günther (Ostariophysi, Characiformes, Characidae). Comunicações do Museu de Ciências e Tecnologia da PUCRS, série Zoologia, 11: 19-59.

Lucena, C. A. S. \& N. A. Menezes. 2003. Subfamily Characinae. Pp. 200-208. In: Reis R. E., S. O. Kullander \& C. J. Ferraris Jr. (Orgs.). Check list of the freshwater fishes of South and Central America. Porto Alegre, RS, Edipucrs.

Lundberg, J. G., T. M. Berra \& J. P. Friel. 2004. First description of small juveniles of the primitive catfish Diplomystes (Siluriformes: Diplomystidae). Ichthyological Exploration of Freshwaters, 15: 71-82.

Luz, R. K., D. A. Reynalte-Tataje, A. A. Ferreira \& E. ZaniboniFilho. 2001. Desenvolvimento embrionário e estágios larvais do mandi-amarelo Pimelodus maculatus. Boletim do Instituto de Pesca, São Paulo, 27: 49-55.

Maciel, C. M. R. R., A. M. Júnior, J. L. Donzele, E. A. T. Lanna \& E. Menin. 2009. Desenvolvimento morfológico das larvas de Hoplias lacerdae Miranda Ribeiro, 1908 (Characiformes, Erythrinidae), da eclosão até a metamorfose, relacionado com a capacidade de capturar alimento exógeno. Biotemas, 22: 103-111.

Marques, C., L. S. O. Nakaghi, F. Faustino, L. N. Ganeko \& J. A. Senhorini. 2008. Observation of the embryonic development in Pseudoplatystoma corruscans (Siluriformes: Pimelodidae) under light and scanning electron microscopy. Zygote, 16: 333-342.

Matkovic, M. \& A. Pisanó. 1989. Estudio macro y microscopico del desarrollo de Hoplias m. malabaricus (Pisces, Erythrinidae). I: Fase larval. Revista Brasileira de Biologia, 49: 553-569.

Mattox, G. M. T. \& M. Toledo-Piza. 2012. Phylogenetic study of the Characinae (Teleostei: Characiformes: Characidae). Zoological Journal of the Linnean Society, 165: 809-915.

Mirande, J. M. 2009. Weighted parsimony phylogeny of the family Characidae (Teleostei: Characiformes). Cladistics, 25: 1-40.

Mirande, J. M. 2010. Phylogeny of the family Characidae (Teleostei: Characiformes): from characters to taxonomy. Neotropical Ichthyology, 8: 385-568.

Nakatani, K., A. A. Agostinho, G. Baumgartner, A. Bialetzki, P. V. Sanches, M. C. Makrakis \& C. S. Pavanelli. 2001. Ovos e larvas de peixes de água doce: desenvolvimento e identificação. Maringá, Paraná, EDUEM.

Nakatani, K., G. Baumgartner \& M. S. T. Baumgartner. 1997. Larval development of Plagioscion squamosissimus (Heckel) (Perciformes, Sciaenidae) of Itaipu Reservoir (Paraná River, Brazil). Revista Brasileira de Zoologia, 14: 35-44.

Ninhaus-Silveira, A., F. Foresti \& A. Azevedo. 2006. Structural and ultrastructural analysis of embryonic development of Prochilodus lineatus (Valenciennes, 1836) (Characiforme; Prochilodontidae). Zygote, 14: 217-229.

Nogueira, L. B., P. G. Azevedo, M. R. Canelhas, A. G. Bedore, J. M. Lopes \& H. P. Godinho. 2012. Induced spawning and early ontogeny in hatchery-reared catfish Zungaro jahu (Siluriformes: Pimelodidae). Neotropical Ichthyology, 10: 89-98.

Nogueira, L. B., A. L. Godinho \& H. P. Godinho. 2014. Early development and allometric growth in hatchery-reared characin Brycon orbignyanus. Aquaculture Research, 45: 1004-1011.

Oldani, N. O. 1983a. Identificacion y morfologia de larvas y juveniles de Pimelodus maculatus Lacépède 1803 (Pisces, Pimelodidae). Revista de la Asociación de Ciencias Naturales del Litoral, 14: 193-202.

Oldani, N. O. 1983b. Identificacion y morfologia de larvas, juveniles y adultos de Mylossoma paraguayensis Normal, 1929 (Pisces, Characidae). Studies on Neotropical Fauna and Environment, 18: 89-100.

Oliveira, E. C., A. Bialetzki \& L. F. Assakawa. 2008. Morphological development of Hypophthalmus fimbriatus and H. marginatus post-yolk-sac larvae (Siluriformes: Pimelodidae). Zootaxa, 1707: 37-48.

Oliveira, F. G., A. Bialetzki, L. C. Gomes, M. Santin \& T. L. Taguti. 2012. Desenvolvimento larval de Brycon hilarii (Characiformes, Characidae). Iheringia, Série Zoologia, Porto Alegre, 102: 62-70.

Pena, J. C., R. M. Sanchez \& M. M. Jamett. 1988. Desarrollo embrionario, larval y del alevin de Cichlasoma dovii (Günther, 1864) (Pisces: Cichlidae). Revista de Biologia Tropical, 36: 417-422.

Perini, V. R., Y. Sato, E. Rizzo \& N. Bazzoli. 2010. Biology of eggs, embryos and larvae of Rhinelepis aspera (Spix \& Agassiz, 1829) (Pisces: Siluriformes). Zygote, 18: 159-171.

Perini, V. R., Y. Sato, E. Rizzo \& N. Bazzoli. 2013. Comparative analysis of the oocytes and early development of two species of Curimatidae teleost fish. Anatomia, Histologia, Embryologia, 42:40-47.

Ponton, D. \& S. Mérigoux. 2001. Description and ecology of some early life stages of fishes in the River Sinnamary (French Guiana, South America). Folia Zoologica, 50: 1-116.

Prokes, M., A. Perez Martínez \& M. Peñáz. 1987. Development of Cichlasoma tetracanthum in the posthatching period. Folia Zoologica, 36: 371-383.

Reis, R. E., S. O. Kullander \& C. J. Ferraris Jr. 2003. Check list of the freshwater fishes of South and Central America. Porto Alegre, RS, Edipucrs. 
Ribeiro, C. R., H. S. L. Santos \& A. A. Bolzan. 1995. Estudo comparativo da embriogênese de peixes ósseos (Pacu, Piaractus mesopotamicus; Tambaqui, Colossoma macropomum e híbrido Tambacu). Revista Brasileira de Biologia, 55 (supl. 1): 65-78.

Rodrigues-Galdino, A. M., C. V. Maiolino, M. Forgati, L. Donatti, J. D. Mikos, P. C. F. Carneiro \& F. S. Rios. 2010. Development of the neotropical catfish Rhamdia quelen (Siluriformes, Heptapteridae) incubated in different temperature regimes. Zygote, 18: 131-144.

Sanches, P. V., K. Nakatani \& A. Bialetzki. 1999. Morphological description of developmental stages of Parauchenipterus galeatus (Linnaeus, 1766) (Siluriformes, Auchenipteridae) on the floodplain of the Upper Paraná River. Revista Brasileira de Biologia, 59: 429-38.

Santos, J. E. \& H. P. Godinho. 2002. Ontogenic events and swimming behavior of larvae of the characid fish Salminus brasiliensis (Cuvier) (Characiformes, Characidae) under laboratory conditions. Revista Brasileira de Zoologia, 19: 163-171.

Severi, W. \& N. F. Verani. 2006. Morphological development of Pellona flavipinnis post-yolk-sac larvae and juveniles (Clupeiformes: Pristigasteridae). Zootaxa, 1126: 21-33.

Silva, A. C. G., W. Severi \& M. F. Castro. 2010. Morphological development of Anchoviella vaillanti (Steindachner, 1908) (Clupeiformes: Engraulidae) larvae and early juveniles. Neotropical Ichthyology, 8: 805-812.

Sousa, W. T. Z. \& W. Severi. 2002. Desenvolvimento inicial de larvas de Rhaphiodon vulpinus Agassiz (Characiformes, Cynodontidae). Revista Brasileira de Zoologia, 19: 85-94.

Taguti, T. L., D. Kipper, A. Bialetzki, P. V. Sanches, M. C. Makrakis, G. Baumgartner \& R. Fernandes. 2009. Desenvolvimento inicial de Pyrrhulina australis Eigenmann \& Kennedy, 1903 (Characiformes, Lebiasinidae). Biota Neotropica, 9: 59-65.
Taylor, W. R. \& G. C. Van Dyke. 1985. Revised procedures for staining and clearing small fishes and other vertebrates for bone and cartilage study. Cybium, 9: 107-119.

Toledo-Piza, M. 2000. Two new Heterocharax (Teleostei: Ostariophysi: Characidae), with a redescription of $H$. macrolepis. Ichthyological Exploration of Freshwaters 11: 289-304.

Virta, V. C. \& M. S. Cooper. 2009. Ontogeny and phylogeny of the yolk extension in embryonic cypriniform fishes. Journal of Experimental Zoology (Molecular Development and Evolution) 312B: 196-223.

Walter, B. E. 2012. Early ontogeny of aquarium-raised Moenkhausia sanctaefilomenae (Characiformes: Characidae). Ichthyological Research, 59: 95-103.

Weber, A. A., F. P. Arantes, Y. Sato, E. Rizzo \& N. Bazzoli. 2013. Oocyte adhesiveness and embryonic development of Astyanax bimaculatus (Linnaeus, 1758) (Pisces: Characidae). Zygote, 21: 198-202.

Weber, A. A., Y. Sato, E. Santos, E. Rizzo \& N. Bazzoli. 2012. Eggs ultrastructure and early development of Franciscodoras marmoratus (Pisces: Doradidae). Anatomia, Histologia, Embryologia, 41: 177-183.

Weitzman, S. H. \& L. R. Malabarba. 1999. Systematics of Spintherobolus (Teleostei: Characidae: Cheirodontinae) from eastern Brazil. Ichthyological Exploration of Freshwaters, 10: 1-43.

Submitted June 25, 2013

Accepted January 20, 2014 by Luiz R. Malabarba

Published June 30, 2014 